\title{
Synchronizing between Lasswell's Communication Model and Abrams' Critical Orientation as a Sophisticated Concept of Literary Communication and Its Associated Studies
}

\author{
Sarif Syamsu Rizal \\ Universitas Dian Nuswantoro, Semarang \\ (sarif.syamsu.rizal@dsn.dinus.ac.id) \\ Article History: Submitted Januari $2^{\text {nd }}, 2020$; Accepted March 10 $0^{\text {th }}, 2020$; Published March $13^{\text {th }}, 2020$
}

\begin{abstract}
This scientific article is entitled "Synchronizing between Lasswell's Communication Model and Abrams' Critical Orientation as a Sophisticated Concept of Literary Communication and Its Associated Studies". By using a multidisciplinary study, one study in solving a problem using various points of view of many relevant sciences in this case, such as literature and communication science, the research question of this article is synchronizing between Lasswell's Communication Model and Abrams' Critical Orientation as a Sophisticated Concept of Literary Communication and Its Associated Studies. The literature review used as a scientific foundation in conducting this theoretical review, among others, is Nature of Literature and Literary Works, Sigmund Freud's Psychoanalytic: Mind Structure and Topography, Intertextuality Act, Mayer Howard Abrams' Critical Orientation, and Harold Dwight Lasswell's Communication Model. The design of this article represents a theoretical review of a comparative study between communication science and literary studies. The technique of data analysis used is Lasswell's model to describe components of literary communication and its associated studies. The results of this article are the components of literary communication consisting of the source as the ideas, the artist as the communicator, the main idea in literary work as the message, the figurative language as media, and the audience as the receiver, and impact as the effect. The studies of each component are that mimetic, expressive, objective, and pragmatic studies.
\end{abstract}

Keywords: communication, component, model, studies, synchronizing

Abstrak. Artikel ilmiah ini berjudul "Sinkronisasi antara Model Komunikasi Lasswell dan Orientasi Kritis Abrams sebagai Konsep Canggih Komunikasi Sastra dan Studi Terkait". Dengan menggunakan studi multidisiplin, satu studi dalam memecahkan masalah menggunakan berbagai sudut pandang banyak ilmu yang relevan dalam kasus ini, seperti sastra dan ilmu komunikasi, pertanyaan penelitian dari artikel ini adalah sinkronisasi antara Model Komunikasi Lasswell dan Orientasi Kritis Abrams sebagai Konsep Canggih Komunikasi Sastra dan Studi Terkait. Tinjauan literatur yang digunakan sebagai landasan ilmiah dalam melakukan tinjauan teoretis ini, antara lain adalah Sifat Karya Sastra dan Sastra, Psikoanalitik Sigmund Freud: Struktur dan Topografi Pikiran, Tindakan Antartekstualitas, Orientasi Kritis Mayer Howard Abrams, dan Model Komunikasi Harold Dwight Lasswell . Desain artikel ini merupakan tinjauan teoritis studi banding antara ilmu komunikasi dan studi sastra. Teknik analisis data yang digunakan adalah model Lasswell untuk menggambarkan komponen komunikasi sastra dan studi terkaitnya. Hasil dari artikel ini adalah komponen komunikasi sastra yang terdiri dari sumber sebagai ide, artis sebagai komunikator, ide utama dalam karya sastra sebagai pesan, bahasa kiasan sebagai media, dan audiens sebagai penerima, dan dampak sebagai efek. Studi masing-masing komponen adalah studi mimesis, ekspresif, objektif, dan pragmatis.

Kata kunci: komunikasi, komponen, model, studi, sinkronisasi 


\section{INTRODUCTION}

As social beings, humans always want to connect with other humans. They want to know the surrounding environment, even want to know what is happening to them. This curiosity forces humans to communicate.From this phenomenon, the communication is a very fundamental requirement for a person in social life. The communication and community are two words that cannot be separated from each other. Without communication it is impossible for society to establish, on the contrary without society it is impossible for humans to develop communication.Harold D Laswell, one of the founders of the foundation of communication through political science, mentioned three basic functions of communication. First, it is a human desire to control their environment. Through communication, humans can find out whether the existing opportunities can be used tomaintain and avoid the threat to the surrounding nature. Through communication, humans can find out an event. Even through communication,human can develop knowledge, namely learning from experiences, and through the information from the surrounding environment. Second, it is a human effort to be able to adapt to their environment. The process of continuing a society actually depends on how the community can adapt to its environment. An adjustment lies not only in the ability of humans to respond to natural phenomena such as floods, earthquakes and seasons that affect human behavior, but also the environment in which people live in challenges. In this environment, adjustments are needed so that humans can live in a harmonious atmosphere. Third, it is an effort to transform the legacy of socialization. To maintain the existence of a society, the members of the community are required to exchange values, behavior, and roles. For example, how parents teach good social manners to their children, how schools function to educate citizens, how the mass media channel the conscience of the public, and how the government with wisdom protects the interests of community members. These three functions become a basic benchmark for each individual in dealing with other community members, and communication is clearly inseparable from the human lives, both as individuals and as members of society. The communication is trying to bridge the thoughts, feelings, and needs of a person with the outside world. It builds human contacts by showing themselves and trying to understand the will, attitudes and behavior of others and makes one's horizons broader.

As what Wijaya explained in his book that human beings are instinctively in accordance with their nature either as individuals or social beings.

As social creatures, humans want to get attention in their groups in various ways. Thus, someone with another needs to live and communicate, among others, namely living in society, in a community, living in groups, in friends, in family, and in the nation. Between groups of people with other groups or with other communities not always close together but they live separately. Under these conditions, communication is clearly needed for people to exchange information (2000: 64).

The communication in a broader sense is not only interpreted as the exchange of news and messages but as individual and group activities regarding exchanging data, facts, and ideas. The theoretical and practical benefits of the communication are as follows. The theoretical benefits of the communication include providing information, providing entertainment, influencing others, knowing oneself and others, knowing the outside world, creating and maintaining meaningful relationships, changing attitudes and behaviours, helping others, and expressing needs and interests. While the practical benefits of the communication include channelling our expressions, connecting with fellow human 
beings, familiarizing us with others, knowing the news, facilitating relationships with others (Nurudin, 2005:14-15, Rachmat, 1984:55).

In everyday life, humans need a medium or tool to convey messages to others. The most frequent and easy to use tool is language. Besides being able to describe something clearly, language is also owned and known by individuals from birth so that someone does not have difficulty in its use.Not only in communication and everyday social interaction processes, but language alsoturns out to have an important role in literary communication. Of some literary products such as poetry, short stories, or even novels, of course, the language influences the value of the literary work. A person's ability in literature can be seen from his language, including how the person processes words to describe what he is thinking and the reader enjoys literature created by someone who is an expert in his field. The success of someone creating a literary work is assessed by how much influence the work has on the reader whether the message can be captured according to the author's intention or not.From the discourse above, literature is a tool for communication, so the literature includes the principles of communication, such as communicators, media or channels, communicants, influence, and feedback. The principle of communication referred to in literature relates to literary writers, connoisseurs and readers of literary works, and literary works. Influence and feedback related to literary expectations and literary motives to create a literary work. Literary works have the effect that is expected by the writers with the emergence of literary discourse.

Responding to two scientific discourses between communication and literature, the writer conducts comparative study research between the two in order to find the components that exist in the process of literary communication and studies related to each of the existing component. In conducting this literarystudy, he collected data from both communication theory and literary theories as a scientific foundation to find the answers to the problems of this study. The theoretical basis used is as follows.

\section{Nature of Literature and Literary Works}

Sumardjo and Saini (1997: 3-4) stated that literature represents a human personal expression of experiences, thoughts, feelings, ideas, enthusiasm, beliefs in a form of concrete images that evoke enchantment with language tools. It has components in the form of thoughts, experiences, ideas, feelings, passion, beliefs, expressions, forms and languages. This is confirmed by Saryono (2009: 16-20) that literature also has the ability to record all natural and supernatural empirical experiences, in other words, literature is able to be a witness and commentator of all life in the universe.

To Luxemburg (1984: 23), literature is not just an artifact like inanimate objects, but it is a living figure. As a living figure, literature develops dynamically with other figures, such as politics, economics, art, and culture. It is also considerably capable of being a guide to the path of truth because of being written with full of honesty, silence, sincerity, wisdom, and human dignity. It is able to remind, awaken, and return humans to the way they should be, that is the way of truth in an effort to fulfill the tasks of their lives. The literature represents a social phenomenon in a given time because it is written in a certain period of time associated withthe norms and customs of a society and a literary writer is a part of a society and places himself as a social member of that society.

Wellek and Warren (1984: 22) also stated that literature is not just a document of facts; it is not just the collection of real events though it may happen in real life. Literature can create 
its own world as a product of the unlimited imagination in the forms of prose, poetry, and play, and argued that reality in works of fiction is an illusion of reality and a convincing impression that is displayed, but not always an everyday reality. The means to create illusions that are used to entice the reader into entering impossible or extraordinary situations is by complying with the details of the reality of daily life. The situational truths are deeper truths than just obedience to everyday reality. In that way, he will change things that feel bitter and painful if experienced and felt in the real world, but it becomes fun to contemplate in literary works.

\section{Sigmund Freud's Psychoanalytic: Mind Structure and Topography}

A concept of Freud's Psychoanalytic explained that the structure and topography of mind is a description of the human's personality development. It consists of mind structure; id, ego, and superego. The id is based on the pleasure principle and wants whatever feels pleasant at the time, with no consideration for the reality of the situation. The ego is based on the reality principle and understands that other people have needs and desires as well as that sometimes being impulsive or selfish can hurt us in the long run. The ego's job is to meet the needs of the id while taking into consideration the reality of the situation. The superego is a moral part and develops due to the moral and ethical restraints placed on caregivers. Many equate the superego with the conscience as it dictates the norm and belief of the rights and wrongs.

The topography of the mind is a description of awareness levels. It consists of unconscious, subconscious, and conscious. The awareness is stored inconsciousness. It makes up a very small part. In other words, at any given time, the awareness of a very small part of what makes up personality; most of it is buried and inaccessible. The subconscious is the part that can be accessed if prompted but is not in the active conscious. It is right below the surface but still buried somewhat unless being searched. Information is stored in the subconscious. Because the unconscious is so large, and because the awareness of the very small conscious at any given time, this theory has been likened to an iceberg, where the vast majority is buried beneath the water's surface. The water, by the way, would represent everything that not aware of, has not experienced, and that has not been integrated into personalities, referred to as the non-conscious (Freud, 1989: 13-17).

\section{Intertextuality Act}

Intertextuality refers to a state in which every text is associated withand generates other texts (Worton and Still, 1990:7). It refers to the literal and effective presence in a text of another text (Allen, 2000:35). It is not true that works are created by their literary writers. Works are created by works, texts are created by texts, and all together they speak to each other independently of the intentions of their literary writers (Plett, 1991: 93). The concept of intertextuality reminds us that each text exists in relation to others. In fact, texts owe more to other texts than to their own makers (Foucault, 1974, 23).

In Semiotics, intertextuality is a hypogram. It is an act to describe meanings of the relationship among poetries in literary texts is appropriately needed as Riffaterre stated in Pradopo (2010: 299) is that poem is an answer or a response to the previous poem. This means that the poem with one another is the answer from the previous poem. Without placing the poem in historical order, the actual meanings of the poem will not be revealed. According to Riffaterre quoted in his book, Teeuw believed that literary works are not born in a cultural vacuum. Literary works exist as a means of communication, the meanings of 
which can be in deviations or responses from previous literary works. This is because the literary works are born from social phenomena and social conflicts that literary works are created; therefore those were born not in a cultural vacuum but from all forms of social problems that are poured into literary works. Those have implied meanings that must be peeled deeply. With the existing symptoms and conflicts, the poet absorbs and appreciates the events that are transformed into poetry (2003: 67). This transformation is referred to as the hypogram by Rifatterre (1978: 23) cited in Pradopo (2005: 300). In another sense, the hypogram is a sign system that contains at least a statement that can be as large as a text, can only be in the form of potential so that it appears in the linguistic level, or it can be actual so that it is seen in the previous text. Thus, it can be interpreted that the hypogram is the text that cannot be separated from the previous texts which are the background of the creation of new texts.

\section{Mayer Howard Abrams’ Critical Orientation}

M H Abrams in his book The Mirror and the Lamp divided the critical theory of literature into four kinds. Any adequate theory takes some account of all the four components but tends to derive from one of these his principal categories for defining, classifying and analyzing a work of art. Application of this analytical scheme sorts attempts to explain the nature and worth of a work of art into four broad classes. This explains the work of art principally by relating it to another thing namely the universe, the audience, and the artist and the work by considering it in isolation, as an autonomous whole, whose significance and value are determined without any reference beyond itself. Those are mimetic, pragmatic, expressive, and objectivetheories.

The mimetic theory focuses on the relation between the literary text and the extra-textual universe which provides the source and stimulus for what the literary text actually represents. Although calling these mimetic theory which means imitative is in part a sign of its relatively low regard for it, the key point here is that one kind of critical theory of literature focuses, in making sense of what literature means and what is significant about it, upon the relation between the literary text and the extra-textual contexts which the literary text reflects, refracts, refers to, responds to, represents, and or transforms, in one way or another. The pragmatic theory focuses on the relation between the literary text and the reader of the literary text. This kind of critical theory makes sense of what literature means and what is significant about it by focusing attention upon what kinds of impacts it exerts and what the effects to its readers. Abram calls this theory as 'pragmatic' adopting froma history of classical rhetorical theory and criticism which studied literature, together with other kinds of speech and writing, in terms of how it could be deliberately constructed to achieve particular effects with particular audiences. Much ancient and classical literary theory understood literature as deliberately written to do something to and for its audience. The expressive theory focuses on the relation between the literary text and the artist of the literary text. This kind of critical theory of literature, which only became prominent with the Romantic movement in the early 19th century, makes sense of the meaning and significance of literature by focusing upon what the literary text expresses about the thoughts and feelings of its artist or, in cases where it is not clear what the writer thinks and feels, about those of 'the speaker' or 'the narrator' in the text. The objective theory focuses on the relation between the literary text and its distinctively literary devices (Abrams, 1953: 3-29). 


\section{Harold Dwight Lasswell's Communication Model}

In its process, the communication has a model and each model hasdifferent components. The communication modelaims to understand the model of communication and its basic components needed in thecommunication process. In the communication studies, those models are such as Stimulus-Response Model, Aristotle's Model, Lasswell's Model, Shannon and Weaver's Model, Schramm's Model, Newcomb's Model, Westley and Maclean's Model, Gerbner's Model, Berlo's Model, Deflour's Model, Linear Communication Model, Interactional Model and Transactional Model (Fiske, 1990: 24-38)

H. D. Lasswell, an American political scientist, stated that communication is an activity of delivering information such as messages or ideas, from one party to another. Cited in Shoemaker (2004:120), Steinberg (2007:53), Fiske (1990: 25-30) and Peng (2015), Lasswell's communication model can be summed up as thatcommunication describes an act of communication by defining components of communication into (1) who said it refers to the communicator who formulates the message, (2) what was said is the content of message, (3) in what channel it was said indicates the medium of transmission, (4) to whom it was said describes either a receiver or audience of mass communication, (5) with what effect it was said is the outcome of the message. In this model, the communication components are 'Who' referring to who sends the message called as 'Control Analysis', 'Says what' referring to what the message says about called as 'Content Analysis', 'In which channel' referring to what channel used to send the message called as 'Media Analysis', 'To Whom' referring to whom receive the message called as 'Audience Analysis' and 'With What Effect' referring what impacts of the receiver called as 'Effect Analysis'.

\section{METHOD}

By using a multidisciplinary study, a study in solving a problem using various points of view of many relevant sciences in this case, such as literature and communication science,the research question of this article is to synchronize between Lasswell's Communication Model and Abram's Critical Orientation as a Sophisticated Concept of Literary Communication and Its Associated Studies. Thus, the significancesof the study are as follows. Theoretically, this article is to contribute to the development of science in literature, especially English literatureabout the components of literary communication and associated studies, and practically, to provide a practical basis learning knowledge for readers about components of literary communication and associated studies. In collecting the data, the writer obtains materials to highlight the article by searching the data from any references online and offline associated to research object namely theory of communication science as its formal object and theory of literature as material object. The literature review used as a scientific foundation in conducting this theoretical review, among others, is Nature of Literature and Literary Works, Sigmund Freud's Psychoanalytic: Mind Structure and Topography, Intertextuality Act, Mayer Howard Abrams' Critical Orientation, and Harold Dwight Lasswell's Communication Model. The design of this article represents a theoretical review of the comparative study between communication science and literary studies. The technique of data analysis used is this model to describe components of literary communication and its associated studies. 


\section{RESULTS AND DISCUSSION}

Lasswell stated that communication is an interaction between two or more people that involves the process of sending and receiving messages from the communicator to the receiver. From this statement, the communication process consists of influencing components one another. These components include communicator, message, media or channel, receiver, and effect. Those are the main components in communication that indicate the ongoing communication process. Related to literature, Segers (1978: 24-25) and Ducan (1962: 56) cited in Ratna explained that communication in literature has a specific purpose, whether to transfer ideas, educate, entertain, or change something in order to achieve communication objectives. The entire communication process in literature must run efficiently, each component in the literary communication process must be considered so that it can generate positive effects onthe readers. The followings describe the importance of literary communication components which play a role in the success of its ongoing communication process. This means that in the science of literature, communication is a symptom of the relationships that exist between the literary works and any relationships of the process of its creation.

The components of literary communication can be found by tracing the relationships among the literature and all things that affect its creation process by synchronizingbetween Lasswell's Communication Model and Abrams' Critical Orientation to find literary communication components. The followings determine and define types of the relationships. The result of it constructs an effective communication in literature. By synchronizing Lasswell's and Abrams's theory can be traced the components of the literary communication process as follows. The communicator is the artist, the message is the message what is said in literary works, the media or channel is the language used in literary works, the receiver is the audience, and the effect is feedback. The reviews are schemed as the following.

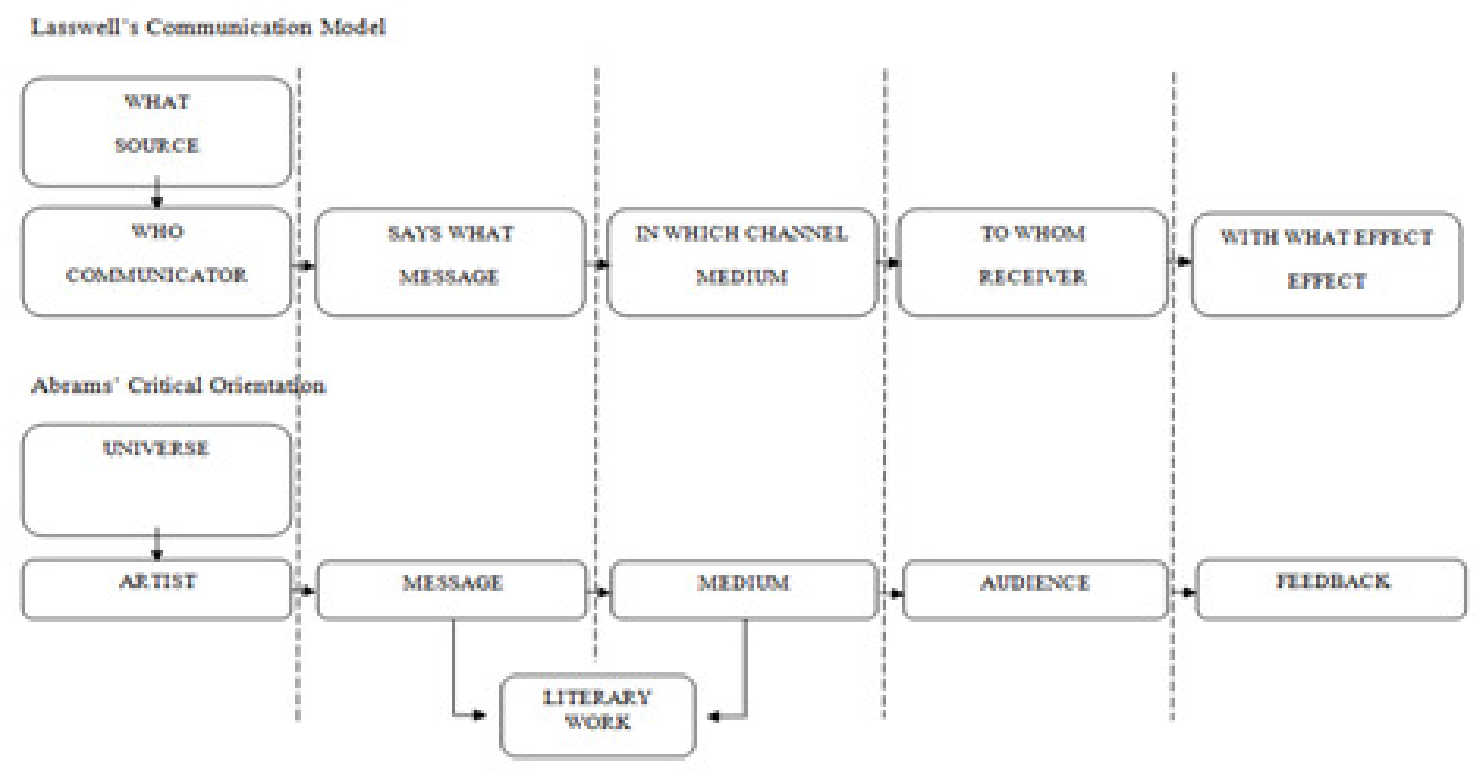

Figure 1 Synchronizing Lasswell's Communication Model and Abrams' Critical Orientation 


\section{Review One is Source}

According to Lasswell's communication model, the source as a startingpoint component in a communication process as the basis used in delivering messages and used in order to complete the message to sent. The source refersto, in this case,the source of ideas as the basis for the message to be delivered by the communicator to the receiver. The ideas are impressions in one's inner world of the communicator. The impression can be a result of thoughts, proposals, desires, and hopes. Furthermore, the idea is complemented with facts, data, information and other supporting issues that are expected to clarify the ideas and at the same time convince the receiver's perspective. Ways of conveying ideas can include storytelling, painting, presentation, and discussion.

According to Abrams' theory, in the process of compiling an idea, its existence is influenced by three factors, namely (1) the universe, (2) personality, and (3) previous works. The source is everything that exists in the universe. The source in question is the source of ideas from the universe. These ideas are mental representations of an objective reality. This reality is the result of the reflection process carried out by the communicator.

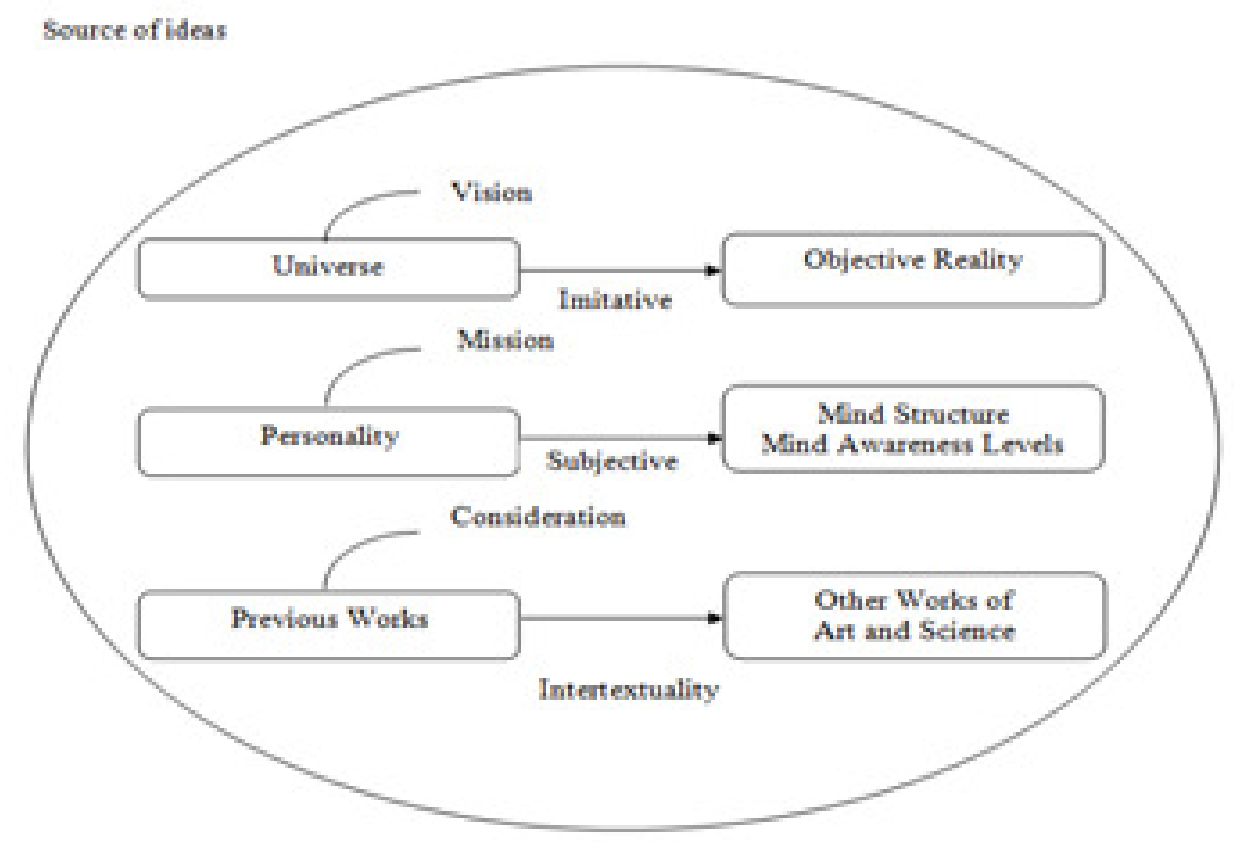

Figure 2 The Factors Influencing Ideas

The first factor influencing the ideas is universe. It is generally defined as the totality of objects and phenomena that occur throughout the cosmos, namely the orderly world in a harmonious system. Contextually, the universe is referred to as the cosmos, the world, or nature and can be referred to as objective reality including real events, norms, and beliefs. The universe is imitative as a communicator's vision. Everything that is experienced by the communicator in the universe during his life is the experience of his five senses so that the vision expresses his ideas.

According to Abrams theory, the ideas that are influenced by the universe are an imitation. Based on the mimesis concept, poetry, a genre of literary works is a reflection according to Plato; he stated that writing poetry is a mimetic process reflecting the world. However, Plato considers that the definition of this poem as a critique of the poem itself. In his philosophy, the world itself is an illusion, which is an imitation of the perfect world that 
shapes a reality; so poetry becomes a mock world of the real world. The mimesis view of poetry has been debated mainly by proponents of realism in art. The main idea of this view is the tendency to see the nature of the universe given as a guide for the nature of poetry. Some keywords in the display of ideas are imitation, image, reflection, forgery, copy, and representation. The universe shows that there is a relationship between the source of ideas and reality.

In the domain of literary studies, the universe is one of the factors that influence ideas in the minds of communicators to produce messages, in this case, communicators are artists. The messages are packaged in literary works, using language as media to send to the receiver. To find out what aspects exist in the universe, in literary research, it is called mimetic study. The mimetic study is a literary study that emphasizes the relationship between literary works and reality outside literary works. This study views literary works as imitations of reality (Abrams 1953: 89). In the process of creating ideas, in the form of literary works and using the language, literary writer, of course, has made careful observations about the phenomena of life in the real world and make reflections on that life before expressing in the message in his literary work. Thus, literary works are basically the response of literary writers to real situations that occur around. This view departs from the thought of Plato and Aristotle that literary works are a reflection of real life. The reflection is realized because it is an imitation and combination of the literary writer's imagination about the reality of nature and life. The mimetic study is one form of literary criticism that analyse the relationship between literary works and reality, the extent to which literary works imagine the reality of life. This study views the literary work as an imitation of aspects of the universe, and the ideas are a reflection of the living world. It is a criterion used by critics is to what extent literary works represent reality. According to Klarer(1999: 93), literary research that focuses on the reality of life is a context-oriented literary study. The term context-oriented study refers to scholars who do not consider literary texts as independent works of art but instead place literary works in context. Depending on the movement, this context can be in terms of historical, social and political conditions, and phenomena of any field in reality.

The view of this mimetic study is an assumption that literary works (noted as messages) are natural imitations and it can be said as depictions of the world and human life in the universe. The basic consideration of this study is the world of experience,namely the literary work itself which cannot represent a realityindeed, but only as an imitation of reality (Abrams, 1953: 8). Reality is used in the broadest sense, that is, everything that is outside of literary works and referred to by literary works, such as objects that can be seen and touched, forms of society, feelings, and thoughts (Luxemberg, 1989: 15). In connection with the mimetic study, Segers (2000: 91-94) revealed the concept used by the Marxists. According to this concept, a hierarchical imitation of art is under reality. However, Marxist and literary sociology view artworks as social documents; artwork as a reflection and reality in it as something that has been interpreted. Klarer (1999: 94-95) explained that the term context-oriented approaches refer to the mimetic studies which do not regard literary texts as self-contained, independent works of art but try to place them within a larger context. Depending on the approach, this context can be historical, social and political, or nationality background. The research objective of this study is a degree to which literary works represent the real world or universe. The relation between reality and fiction in literature is a dialectical relationship. The imitation is not possible without the creation, and the creation is not possible without the imitation. The parameters and linkages between the two can differ according to the writer's culture, literary type, era, and 
personality. Because the one without the others is impossible so the combination of creation and imitation does not only apply to literary writers but its importance to readers' effects. The paradigm in the mimetic study is searching for meanings in literary works. It means an endless journey back and forth between the two, namely the world of reality and the world of fantasy. The literary works that are released from reality will lose something essential, namely the involvement of literary writers in the existence of these literary works.

By reviewing what the theorists said above, one of the components that can influence the creation of a literary work is the reality of social and environmental conditions of which literary writers live, the sociological conditions of society and anthropological environment. The social dynamics and environmental conditions at the time the work was created are very influential components. The fact of the background conditions of society influences the formation of a literary work. The mimetic literary criticism can be in the form of a study as follows namely ideological, political, economic, social, cultural, defence and security conditions of a place, where and when literary works are created. Those are (1) study of ideology, assuming that the ideological conditions of a country affect the results of literary works. Every country that has a different ideology will give birth to different literary works. Ideology reflects the way of thinking of people, nations, and countries. He directs the community towards its ideals. ideology determines the existence of a nation and state as well as guiding the nation and state, (2) study of politics, assuming that the political conditions of a country or region will greatly affect the results of a literary work, and the upheaval of political concessions at a time will affect the results of a literary work, (3) study of economy, assuming the economic conditions of a nation or country will greatly affect the results of a literary work, and (4) study of society, assuming other than ideological, political, economic conditions of a country will also affect the results of a literary work, (5) study of history, assuming historical conditions of a country will also affect the results of a literary work, (6) study of cultural conditions, assuming the cultural conditions of a nation or country will greatly affect the results of a literary work, and (7) study of defence and security conditions, assuming that the defence and security conditions of a country or region will greatly affect the results of a literary work. At least, the six components are the first aspects found in extrinsic components in literary work.

To find relationships between fact and fiction in the mimetic studies is to describe differences between truths in the real world and truth in the fictional world. The fact is factual truth, and the fiction represents situational truth. The truth in the world of fiction is truth that is in accordance with the communicator's beliefs that have been believed to be validity in accordance with his views on matters of life. The truth in fiction does not have to be in line with the truth prevailing in the real world, and the aesthetic distance between fact and fiction is the objectives of this study. The aesthetic distance is the distance between the reality in literary works and the reality that exists in everyday life. The farther distance of reality in literary works when compared to the reality in real life means that literary works are of high quality or value. While the reality in literary works is the same or similar to the real world, the literary works are of low quality, although the raw material of literary works is the reality of daily life, but the reality in literary works has been added to a higher value invention by the author, by this case, the author is the communicator. 


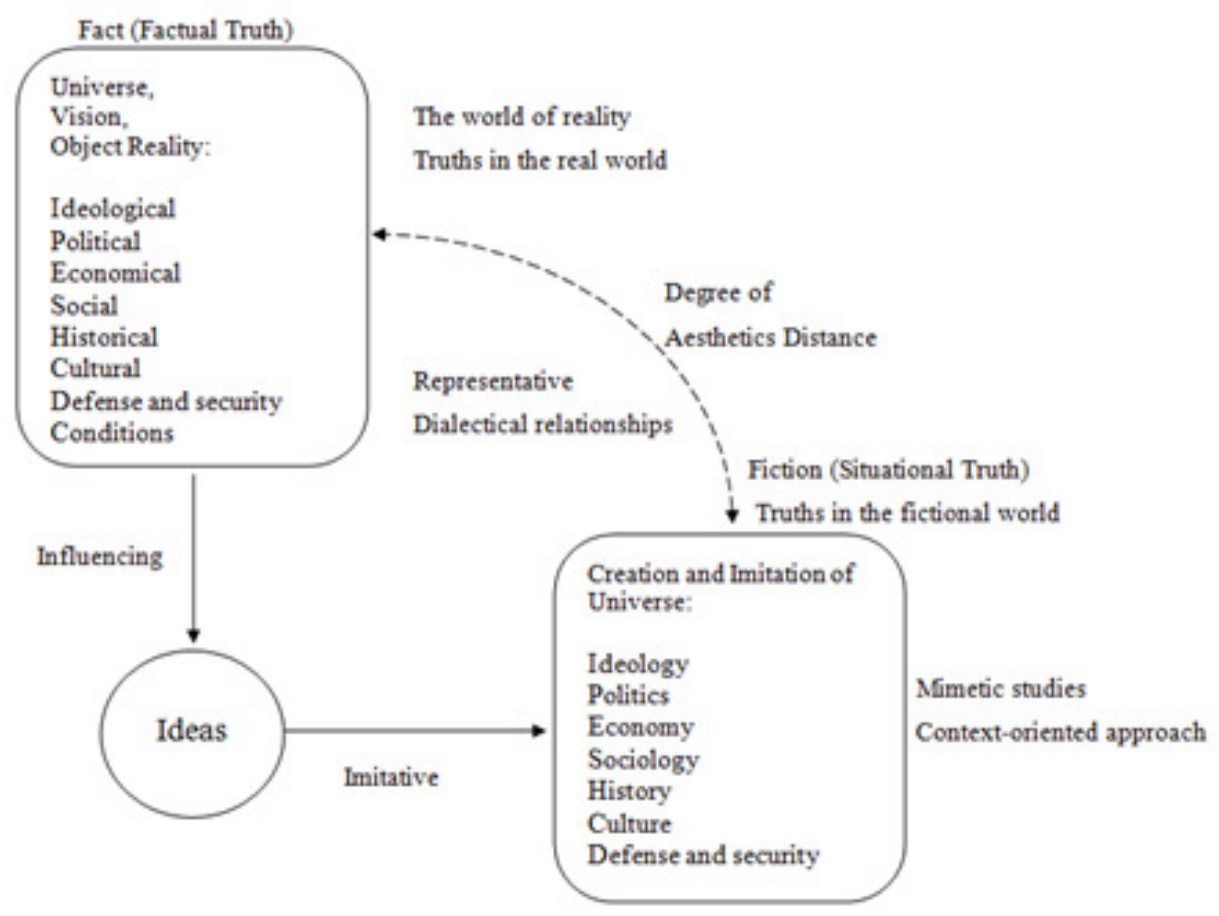

Figure 3 Mimetic Studies

The second factor influencing the ideas is the communicator's personality. The ideas are self-expression of communicator's mind as Kristeva said that everything on the literary writer's mind flows into works in creating process of them. This factor consists of the structure and awareness level of the communicator's mind. Sigmund Freud's psychoanalytic said that human personality consists of major components that work to create a communicator's behaviour. The communicator's behaviour is influenced by his mind structure; id, ego, and superego and his awareness levels; consciousness, subconsciousness, and unconsciousness.

According to Freud's psychoanalytic, the former is the communicator's mind structure. It consists of his id, ego, and superego. The id is a component that is carried from birth. This mind structure is primitive, illogical, irrational, instinctive, and fantasy-oriented part that contains sexual and aggressive drives and hidden memories. It is driven by principle of pleasure for immediate satisfactory of all wants and needs. The ego is a mind structure that is responsible for dealing with reality. It is the realistic part that mediates between the desires of the id and the superego. It develops from the id and ensures that the impulse of the id can be expressed in acceptable ways in the real world. It works based on the principle of relativity which seeks to satisfy the wishes of the id in a way that is realistic and socially appropriate. The superego is a mind structure whose function to develop a personality.It is a component of personality that accommodates all standards of moral internalization and ideals that humans obtain from both parents and society. It operates as a moral conscience. It provides guidelines for making good and bad judgments about everything humans behave.The latter is awareness levels of mind. This covers the conscious, subconscious, and unconscious mind. The conscious level of the communicator serves as a scanner which perceives an event, trigger a need to react, and store it either in the unconscious or the subconscious level of communicator's mind. The other level is the sub-consciousness. The communicator's sub-consciousness is the storage point for any recent memories needed for quick recall. It holds current information that he uses every day, such as his current recurring thoughts, behaviour patterns, habits, and feelings. This 
level serves as the minds random access memory. Thus, it can be seen as the source of dreams and automatic thoughts which appear without any apparent causes; it is as repository of forgotten memories which may be accessible to consciousness at some later time, and as locus of implicit knowledge, its meaning is the things that communicator has learned so well that he does without thinking. The unconscious level is somewhere all of memories and past experiences reside. It is the memories that have been repressed through trauma and have simply been consciously forgotten and no longer important to human mind. The communicator's memories and experiences in this level form his beliefs, habits, and behaviours. This level sits a layer deeper in the mind under his sub consciousness. Although the sub consciousness and unconsciousness has direct links to each other and deal with similar things, the unconsciousness is the underground library of all communicator's memories, habits, and behaviours.

It simply can be summed up that the communicator's mind awareness level is conscious and unconscious. The consciousness covers superego level such as thoughts and perception included social culture; traditions, customs, moral values, religion principles; belief, faith, ideology, philosophy, education. The sub consciousness covers ego level such as stored knowledge, memories. The unconsciousness covers id level such as fear, violent motives, immoral urges, irrational wishes, shameful experiences, selfish needs, unacceptable sexual desires. This factor such is subjective as a mission, which is an important goal or purpose that is accompanied by strong conviction. These factors; mind structures and awareness levels of the communicator indicate that there is a relationship between the ideas and personality.

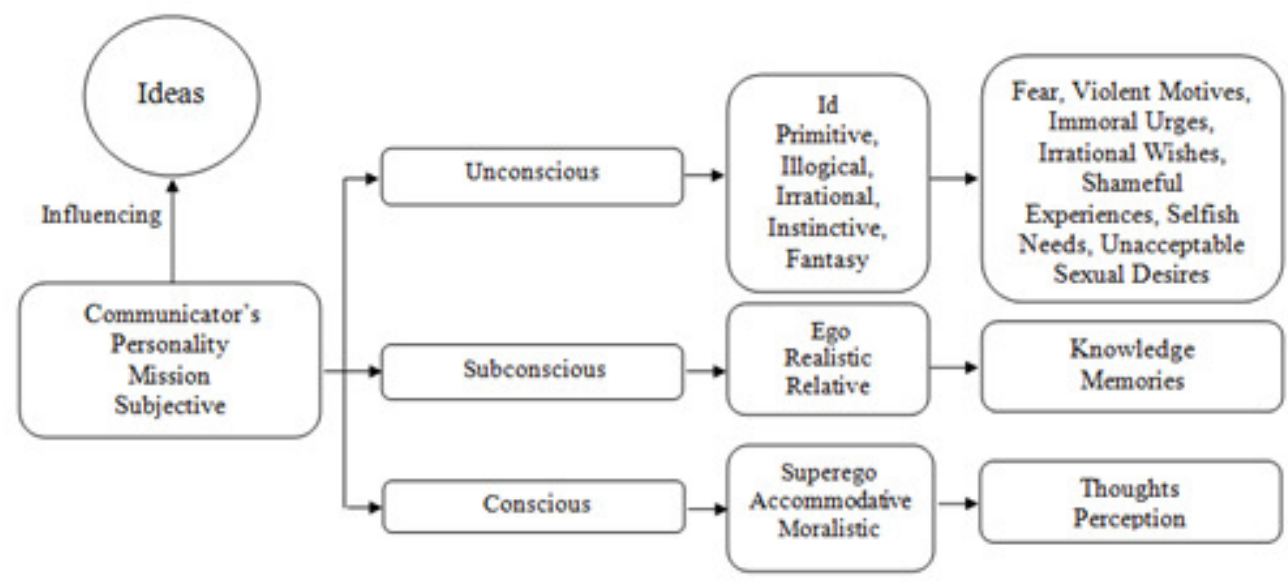

Figure 4 Communicator's Personality

The third factor is the previous works. The previous works can be works of art such as any art namely poetry, prose, and play and the works of science such as anthropology, economics, ethnology, linguistics, psychology, and sociology. The work as the result of creativity cannot exist without references or background of any other proceeded art and knowledge products. Just like whatintertextuality law to be said that the concept of intertextuality reminds that each text exists in relation to others refers to a state in which every text is associated withand generates other, effective presence in a text of another text. This factor is intertextuality as a communicator's consideration, which is something that is to be kept in mind in making a decision. This factor indicates that there is a relationship between the source of ideas and previous works. In semiotics, to find out the meaning in poetry, one form of the message conveyed by the communicator, another method is needed, namely by means of a hypogram, by looking at the meaning of the relationship 
between poems in literary texts. Riffaterre stated in Pradopo (2010: 30) that the poem is a response, an answer, a response to the previous poem. This means that poetry with another poem is the answer to the previous poem that made the poem experiences an ambiguity, contradiction and nonsense. Riffaterre said that the poem was the answer or response to the previous poem. Without putting poetry in historical order, the true meaning of the poem will not be revealed. According to Riffaterre quoted in his book Teeuw believed that literary works are not created in a cultural vacuum. The literary works exist as a means of communication, which means they can be in the form of deviations or responses from previous literary works (1991: 67). It means that literary works are born from social phenomena and social conflicts from the phenomena that literary works are created. Because literary works are born not in a cultural vacuum but rather from all forms of social problems that are poured into literary works, so that literary works have an implied meaning that must be peeled deeply. With the existing symptoms and conflicts, the poet absorbs and appreciates the events that are transformed into poetry. This transformation is referred to as a hypogram by Rifatterre (Pradopo, 2003: 30) In another sense hypogram is a sign system that contains at least a statement that can be as big as a text, can only be in the form of potential so that it can be seen at the level of language, or it can also be actual so that it looks in the previous text (Riffaterre, 1978: 23) So it can be interpreted that the hypogram is the text cannot be separated from the previous text which is the background of the creation of new texts.

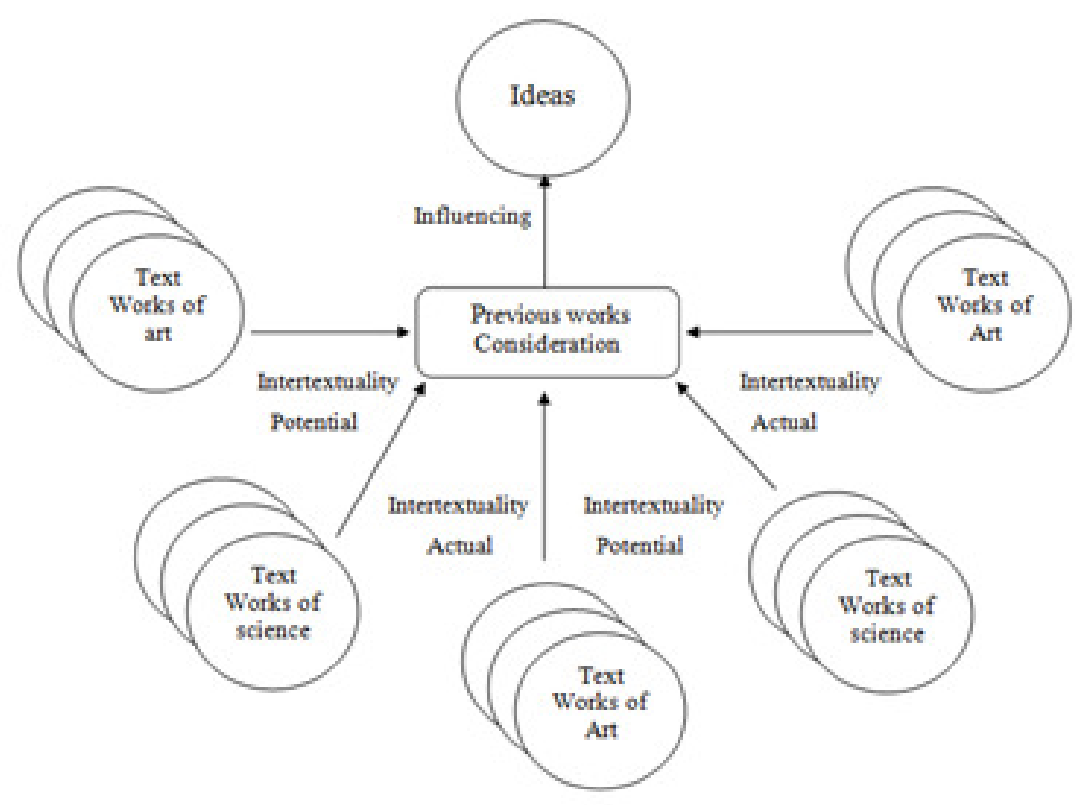

Figure 5 Intertextuality of Previous Works

\section{Review Two is Communicator}

The communicator is the second component of communication process. According to Lasswell, in every form of communication there is always someone who plays a role in conducting communication. Communication experts agree that the communicator is the sender of the message, and the message in this case is the idea that will be sent to the receiver. The form of the message is the result of the sender's contemplation of the above three factors, namely, the universe, personality and previous work. This component can be 
studied through control analysis. The control analysis is a study that emphasizes the question of who sent the message.

In literary studies, a communicator is called an artist. The power of the artist in musing process of source of ideas into messages is subjective. The subjectivity is the ability of the self to express ideas and emotions as catharsis, namely the process of release and relief of emotional pressure. It can be said that the artist is the person who transmits ideas to the message and the power is the creativity possessed by the artist. In the process of literary communication, the communicator is referred to as a literary writer, such as author, poet, and playwright. The author is prose writer, poet is poem writer and playwright is play writer. Literary experts call artists acting as creators, senders, encoders, and producers. As Esten stated, the ability of artists in the process of preparing messages to be sent is creative and imaginative (1978: 9). The artist has the ability to see and then express it in the possibility of problems that occur around him. The creative and imaginative abilities are the ability to imagine and describe the possibilities of life and alternative things experienced by humans.

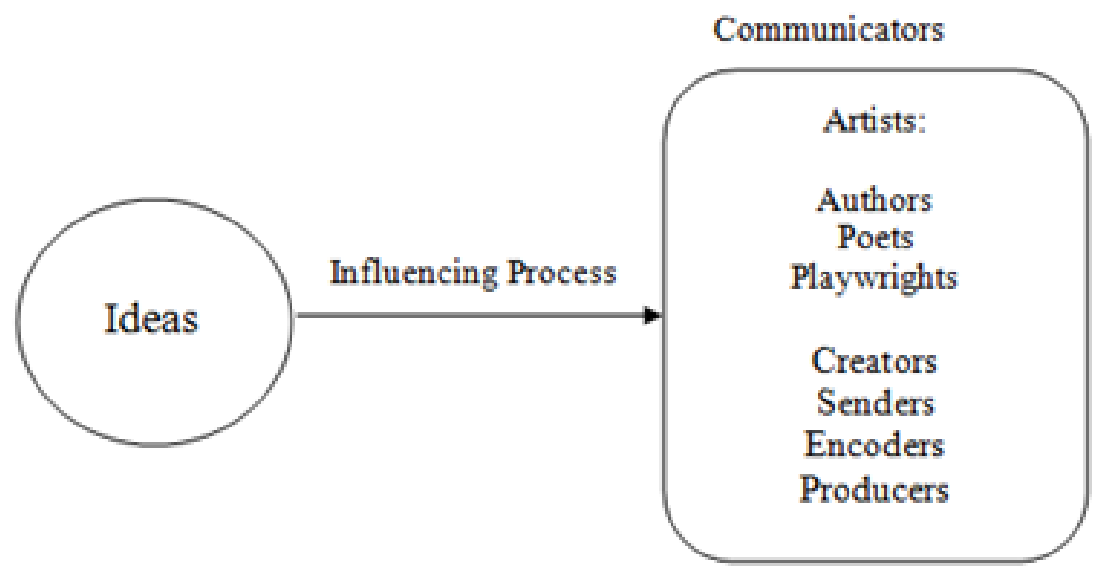

Figure 6 Communicators in Literary Communication

In the literary studies, this component is pointed to expressive study in the literary research. This study tends to directly compare the reality in literary works with the reality experienced by literary writers. This expressive study does not merely focus on how the work was created, but what forms occur in the resulting literary work. Research objectives using this study are to find the literary writer's self, thoughts and feelings, and the results of his work. This study can be used to explore the characteristics or ideological in the work of both individual literary works and literary works within the framework of period.

The expressive studies refers to what Klarer (1999: 91-92) explained that this authororiented approach established a direct relation between the literary text and the biography of the author. Dates, facts, and or events in an author's life are juxtaposed with literary elements of his or her works in order to find aspects which connect the biography of the author with the text. Literary research into the milieu and education of the author is conducted and then related to certain phenomena in the text. Autobiographies are obviously suitable for this kind of approach, which compares the fictional portrayal with the facts and figures from the author's life. Although the characters and events in the literary works are supposedly fictional, they are based on real people and dramatize events from his family life. From the explanation above, the author-cantered approaches focus also on aspects which might have entered the text on a subconscious or unconscious level. 
According to these approaches, the central theme of the literary works, the creation of an artificial human being, can be traced back to intense psychological occupation with the issue of birth at the time. Many authors wish to keep their texts fictional and their private spheres intact and hence oppose these approaches. In addition to, phenomenological approaches assume that the author is present in his text in encoded form and that his spirit can be revived by an intensive reading of his complete works. This has led to psychoanalytic literary criticism, an approach which deals with the author, but primarily attempts to illuminate general psychological aspects in a text that do not necessarily relate to the author exclusively. Under the influence of Sigmund Freud's psychoanalytic literary criticism expanded the study of psychological features beyond the author to cover a variety of intrinsic textual aspects. The interest in psychological phenomena indirectly abetted the spread of the so-called reader-cantered approaches, which focus on the reception of a text by a reader or on the reading process can be seen as investigations of psychological phenomena in the widest sense of the term (Klarer, 1999: 91-92)

According to Abrams (1953: 22) this expressive study putsliterary works as an outpouring, speech, and projection of the thoughts and feelings of the literary writer. The literary writer himself becomes the subject which gives birth to the production of combined perceptions, thoughts, and feelings. The practice of analysis with this study leads to the search for the authenticity of the literary writer's personal vision which in the understanding of genetic structures is called worldview. Often this study maps a number of thoughts, perceptions, and feelings of the literary writer found in his work into several factual categories of text in the form of character, life experience consciously or not reflected in literary works, and literary writer's ideology, literary writer's worldview in individual or social contexts by considering the relations of the text of his literary work with his biographical data. The expressive study is a theory that focuses special attention to the author's creative process in creating literary works. The main cause of the creation of literary works is the creator himself. The reason for the explanation of the personality and life of the author is the oldest and most established method in the study of literature. This expressive study does not merely pay attention to how the work was created but what forms occur in the resulting literary work. Often this study seeks facts about the special character and experiences of writers who consciously or unconsciously opened themselves in these works. As Semi explained in Anatomi Sastra (1984), the literary works cannot be present if there is no one who created them; therefore, the literary writers are very important in their position in the study of literature. The literary work is the pouring of author's thoughts, feelings, experiences, ideas, emotions, and, dreams contained in a literary work. The author's thoughts and feelings are the main source and main problem in a story, for example, the traits and actions derived from the author's thoughts, so that the literary works are a means or tool to understand the state of the author's soul.

Based on Abrams' and Semi's explanation, it can be defined that the objective of expressive study is a study of extrinsic components found in the author's background. The author's background is the factors within the author itself that influence or motivate him to write a literary work and can include an understanding of life history and also the history of previous works. The author's background may consist of (1) artist's biography, a story or information about a person's life. The biography is more complex than just a list of birth or death dates and work data of a person, biography also tells about the feelings involved in experiencing these events. In the biography described in full the life of a character from childhood to old age, even to death. All services, works, and everything that is produced or done by an author are also explained, and biographical texts are composed by others, not 
by himself, (2) psychological conditions of the artist's personality, a condition which is the mood or motivation of an author when writing literary works. This factor affects the results of a literary work, for example if they are sad or happy they will make a sad or happy story, (3) literary movements of the artist, a literary writer definitely follow a certain personal view. This is very influential on the writing style used by the writer in creating a work. The literary movement is a role model believed by an author, and each author has a different literary movement between one author and another, (4) the beliefs of the artist, (5) the artist's ideology, and (6) other aspects associated to the artist's life namely any the results of internalization education from birth obtained from the family and externalization education obtained from the process of social interaction and the fields of science studied during formal and informal education.

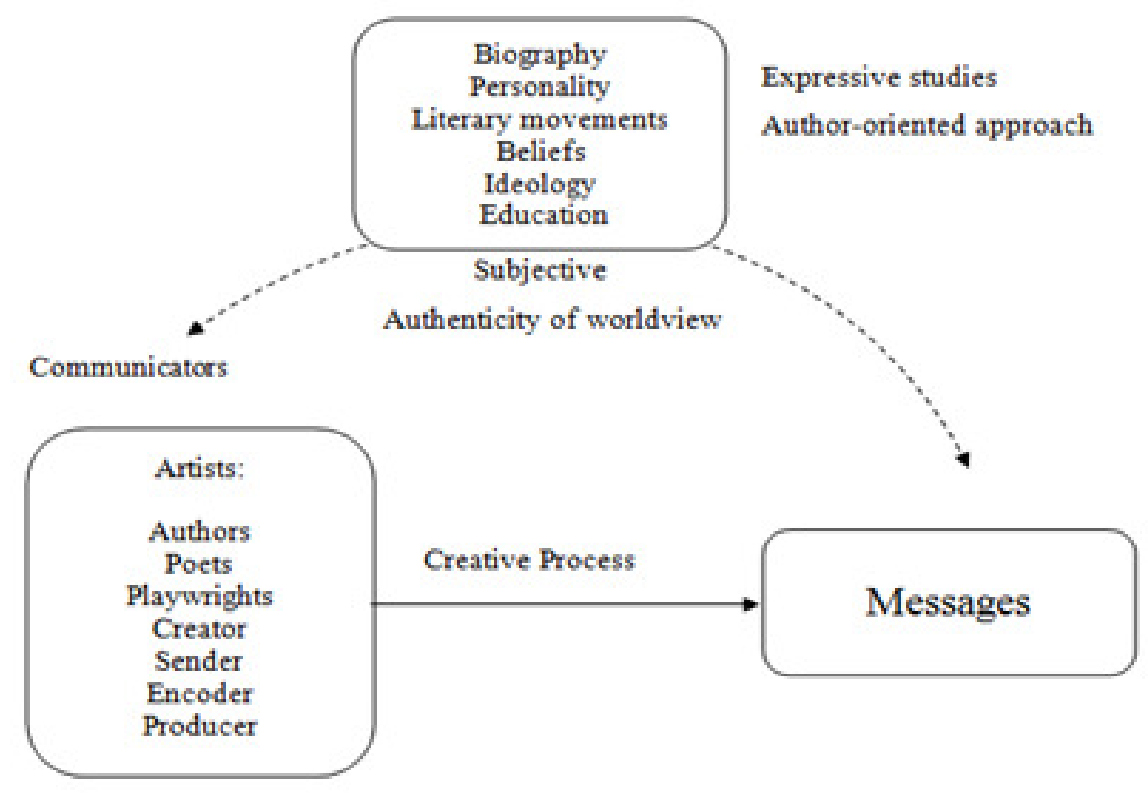

Figure 7 Expressive Studies

\section{Review Three is Message}

The third component of communication process is message. According to Lasswell, the message as one of the components in communication process can be defined as materials given by the communicator to receiver. This component has to be studied through the content analysis by investigating what it says about.

In relation to what Abrams explained that transmitting ideas into message leads to a creativity. The creativity is such a form of personal freedom as a medium to disgorge the artist's ideas from the mass identity he sees all around in which the purpose is to express thoughts, feelings and emotions as a musing process rather than to simply convey information. In the process of creativity composing message, the artist's transmitting ideas into messages may be expressive, imaginative and professional. The message is generally expressed implicitly by which the different aspects of the literary works has. It is only by analysis of those implications that one may reveal the message of a literary work. Therefore, the message in a literary work is not something that is stated in a particular sentence and easily located, but it is something that is comprehended upon reflection. The messages can be conveyed by communicators in various ways, for example through words, tone of voice, gestures and facial expressions. The content analysis is associated to 
representations of ideas in the media. It is required to investigate what the messages say. In literary communication, the most important ideas that the artists expresses in the process of developing a theme is called as message. The theme is therefore organically connected with the artist's message. It is packed up from a main idea or an underlying meaning of a literary work, which may be stated directly or indirectly as the result of transmitting process. The main idea is such the message defined as the theme. The messages in the form of theme as the third component in literary communication can be informative, persuasive, and coercive. The informative messages are those that provide information or facts that guide the receiver to make decisions. The persuasive messages are messages that contain persuasion that aims to provide a change in receiver attitude. The changes that occur are ones that are not forced, but comes from the will of receiver himself. The coercive messages are the opposite of persuasive messages. The coercive message is coercive by relying on sanctions and evidences to suppress the receiver.

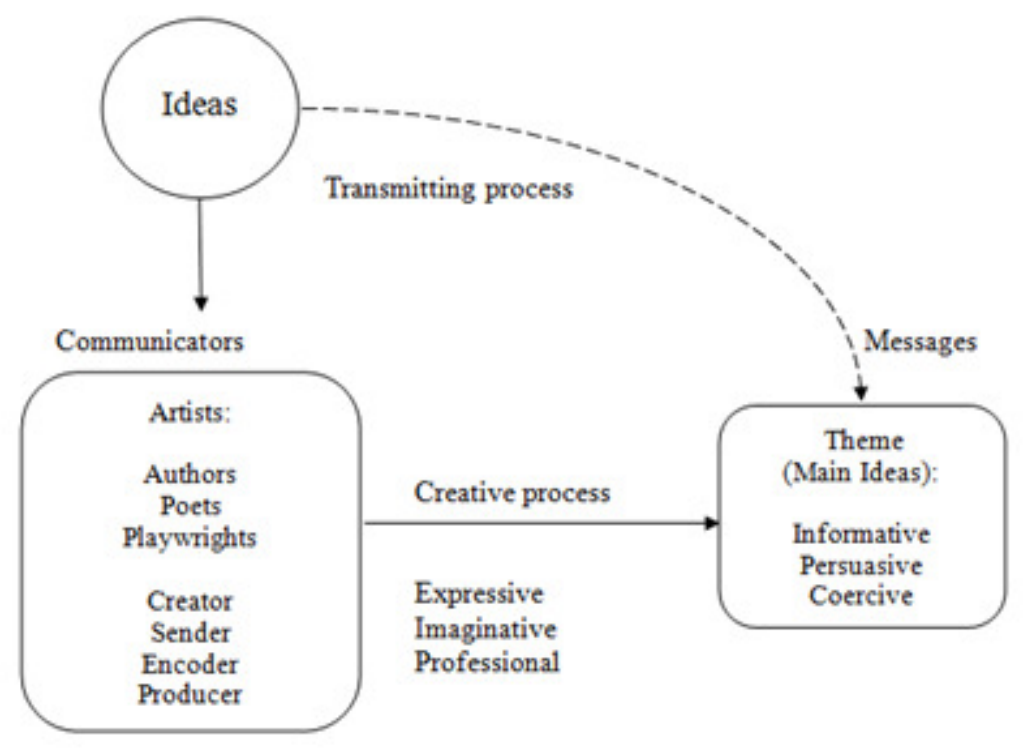

Figure 8 Content Analysis - Messages in Literary Communication

\section{Review Four is Media or Channel}

The media or channel is the fourth component of communication process in delivering messages or often also called communication media. According to Lasswell, this component has to be studied through the media analysis by investigating which medium is the best used to convey a message to receivers as effectively as possible.

This component is used to deliver message inside the literary work presenting the two main functions. That is, the literary work can be said to have high literary value if the work is able to provide entertainment to the readers, as well as being able to provide positive teaching for its readers. The literary works that are only able to provide entertainment without any benefits will be barren. Similarly, literary works that are only able to provide benefits and are not able to provide entertainment for readers will feel bland. Therefore, literature can be said as entertainment media that teach, and entertaining teaching media. The language is a method of human communication, either spoken or written, consisting of the use of words in a structured and conventional way. It is as a system of communication used by a particular community. The language used in delivering the message is literary 
language or figurative language. The characteristics of literary language are namely (1) connotative. The connotative is a word that has an additional meaning or secondary meaning besides the primary meaning. The broader connotation value of the notion of denotation is very important in literary works. Each selected word may be associated with various meanings. Therefore in literature there is no common understanding when viewed from the point of view of sensitivity, from the angle of sound, and from the point of symbol. Each choice of words has its own meaning, for example beautiful words, nice, good, elegant, beautiful, from the point of denotation it may mean the same thing, but the impression of these words has a different sensitivity, (2) symbolic. The literary language is symbolic, meaning that literary language not only expresses the explicit, but also expresses the implied meaning. This is different from the language of journalism which is more literal, (3) multiply interpretative. The multiple interpretations mean multiple interpretations. The language in literature tends to invite double interpretation from its readers. That happens because the connotative nature of literary language and the experience of each reader is different and diverse. In fact, it is often said that the success of a literary work can be seen from the presence or absence of multiple interpretations, and (4) Noting the effect of musicality. The musical effect is a sound effect or sound that can evoke a sense of tuneable. The independence of language sounds in literary works can be raised through the pattern of poetry or rhyme or sometimes formed by repeating the same sound in each verse or sentence.

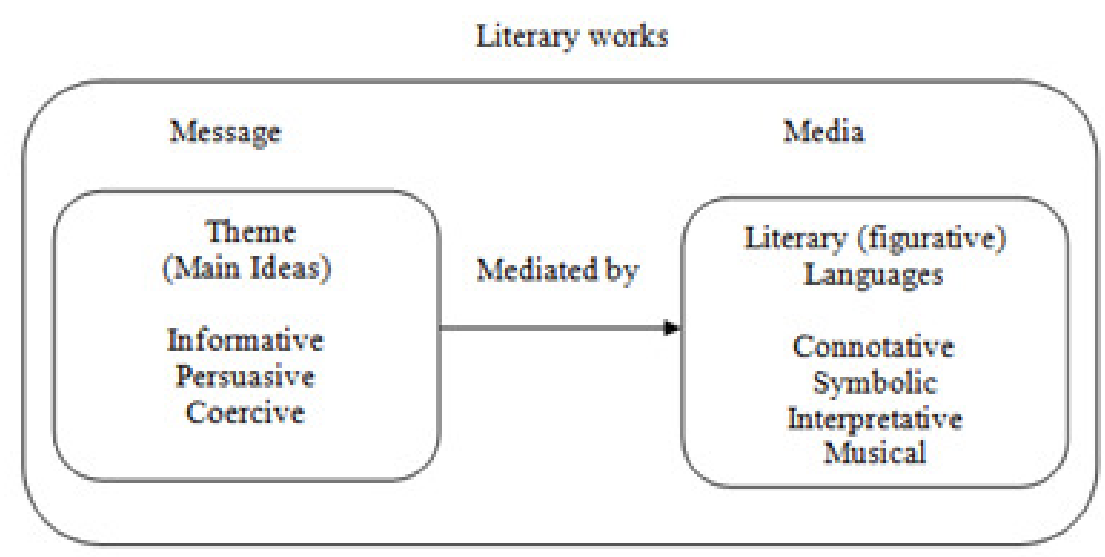

Figure 9 Media Analysis - Channels in Literary Communication

Because the message and media can be found in the literary work, in line with the literary studies, these components are pointed to be objective study in the literary research. The study ((Abrams, 1953: 26-29), (Hawkes cited in Pradopo, 2002: 21)) focuses solely on intrinsic components, interrelationships, and totality in the literary work. Literature research targets that use this study lead to intrinsic analysis. The basic concept of this study is a literary work is a structure consisting of various components forming the structure. Each component does not have a meaning by itself but the meaning is determined by the relationship with other components involved in a situation. The meaning of the components of the literary works can only be understood fully on the basis of the place and function of the components in the whole form of literary work. Methodologically, this study aims to see literary works as a system and the value given to the system is very dependent on the value of the components involved in it. The analysis of literary works through this study depends on the type of literature. The objectives of poetry analysis are different from the prose analysis and the play analysis using this study. Because the message component in literary communication is packaged in the form of literary works 
such as poetry, prose, and play by using language as the delivery medium, the objectives of this study describe the intrinsic component in the literary work and its interrelation in the formation process as the totality of the building factors of the literary work. The major genre of literary work are poetry prose, and play. The intrinsic components of a poem consists of themes, mandates, tones, moods, typography, enjambment, line, rhymes, images, and language styles which the author uses to express his ideas. The structure in prose is formed by intrinsic components, namely theme, plot, setting, characterization, point of view, and mandate. The intrinsic drama component consists of themes, plots, characters, dialogues, characters, and settings. The analysis is to trace the components of literary works and find the relationships and functions of each component.The logical consequence that arises is to reject all extrinsic components, such as historical, sociological, political, and other socio cultural components, including biography. Therefore, the objective study is also called as an autonomy analysis. The emphasis is centred on an analysis of the components by considering interrelationship among components on the one hand and components with totality on the other.

The objective studies according to what Klarer (1999: 78-79) explained that text-oriented approach is centred on the text, primarily investigating its formal or structural features such as Philology which highlights material elements of language; rhetoric and stylistics, the others to analyze larger structures of meaning or means of expression, and the formaliststructuralism, including Russian formalism, the Prague school of structuralism, new criticism, semiotics, and deconstruction, which attempt to trace general patterns in texts or illuminate the nature of literariness.

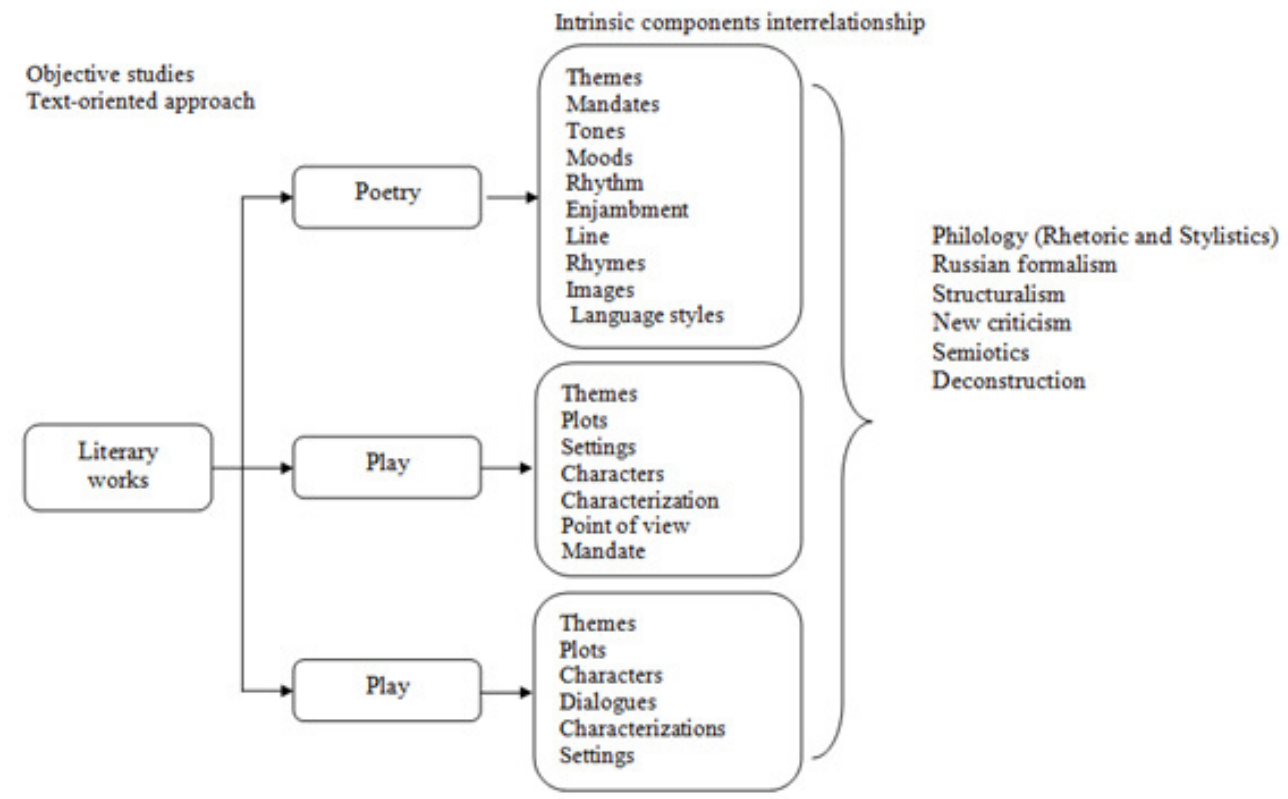

Figure 10 Objective Study

\section{Review Five is Receivers}

The receiver is the fifth component in the communication process. According to Lasswell, audience questions are very important to be successful in concrete communication situations. Audience analysis is used to investigate everything important about the target public message, from gender and age to social status and tastes. In literary communication, 
the receivers can be referred to as readers, recipients, decoders, consumers, critics, translators, or literary researchers.

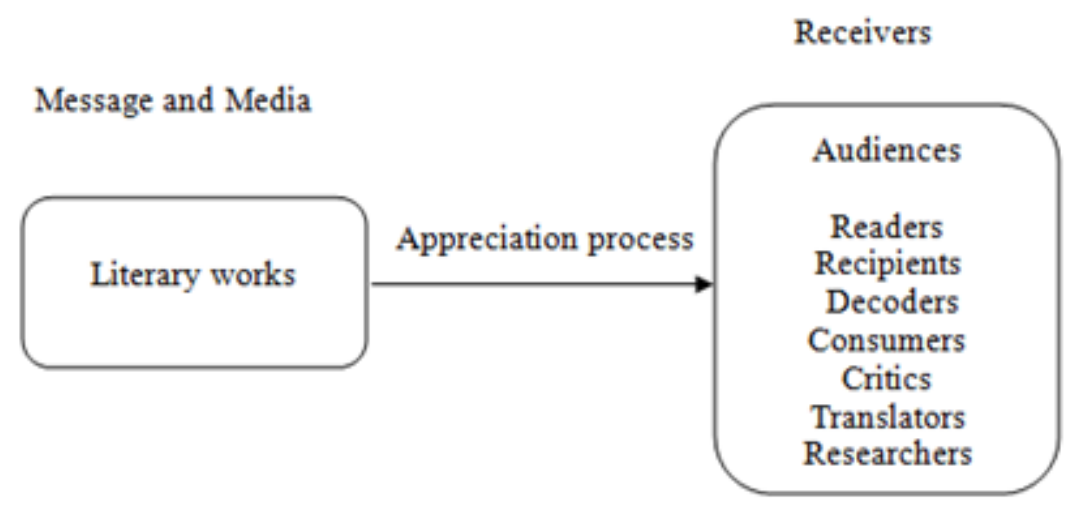

Figure 11 Audience Analysis - Channels in Literary Communication

The relationship between the artist as a literary writer and the receiver as a reader is very typical. This peculiarity can be seen in passing from the nature of communication and communication actors, namely literary writers, language as media, and literary readers. The literary relationship with the reader is very typical of the nature of his communication. That relationship is a reciprocal relationship. The literary writers and readers must be aware that they communicate through literary works. The readers must realize that what they read is a literary work that contains between reality and fantasy. In the world of literature, this presumption is called the literary convention. This convention can cover the language fields of literary works, the contents of literary works, the genre of literary works, the structure of literary works, and the socio-cultural aspects of literary works and the readers can choose, receive, interpreter, give, and arrange the meanings of literary works so as to produce certain values.

In the world of literature, whether it is consciously or not, intentionally or not, eventually literary works reach the readers, and even are shown to the readers. Therefore, whether it is consciously or not, deliberately or not, the reader receives literary works delivered by writers. The recipient can be in understanding, understanding, mocking, rejecting, reading, or carrying out what is in the literary work.Acceptance depends on the responsive level of the readers. There are various levels of readers, namely common literary readers, and mature literary readers; they are critics, and academics. Every reader has his own way of accepting literature. The common reader accepts the literary work with it. The literary reader accepts literary works with his literary schemata. They accept literary works based on their experience in creative processing. The critic reader reads more literary works based on good or bad judgments or the success of a literary failure. The readers who come from academic circles accept literature with scheme of literary theories that they have received. The relationship between the artist and the receiver can also be a relationship that arises due to the attitude and views of the writer towards the role of the reader.

\section{Review Six is Effect}

The sixth component of communication is effect. The effect represents something that is produced by a cause, result, or consequence. From the notation of effects, the effect of reading a literary work is feedback, a consequence of mental impression and emotional impact after reading a literary work. Reading literary works contains two types of readings, 
namely reading literature as entertainment and reading literature as appreciation. According to Lasswell, the consequences of mass communication on the population are one contribution to the concept of effect. Through analysis of effects by investigating how messages can influence the receiver. This component is the end result of the communication process. These effects can vary and $t$ be seen in three categories, namely (1) as a personal opinion, (2) as a general opinion, and (3) as a majority opinion. Personal opinion is the attitude and opinion of someone about a particular problem. Public opinion is a social assessment of an issue based on a thought exchange process. The majority opinion can be understood as an opinion agreed upon by the community.

Based on literary conventions, the effects of literary reading can be seen from the evidence of the benefits of literature for readers. Literature has two main benefits as stated by Horatio, namely dulce et utile, in Latin, sweet and useful. The sweet means very pleasant or enjoyable, while useful means the content is educational (Mikics, 2007: 95). Bressler (1999: 12) calls these two functions with the terms to teach and to entertain. The entertaining means that literature provides its own pleasure in the reader so that the reader feels interested in reading literature. The function of teaching means that literature gives advice and implements ethics so that the reader can emulate positive things in literary works. In this case, literature enables humans to become more human: to know themselves, others, the environment, and various life problems (Sarumpaet, 2010: 1). Form the motioned above, literature and all types of genres have benefits in people's lives. In addition to entertaining, expanding horizons, sharpening conscience, and empathizing with others. Literary experts agree that besides entertainers and educators, the literary function in life is (1) Reactive. The reactive function means that the literature can be entertaining for the reader and the audience. For example, funny stories in a novel, a form of prose, keep readers entertained, or inspiring stories in a literary work make readers more empathetic, (2) Deductive. The literature also educates or educates the reader because in literary works there are various elements and values that we can pick also suitable in everyday life, and (3) Aesthetic. The literature is a beautiful writing so because literature has aesthetic value which can be enjoyed by connoisseurs and readers. It can be summed up that the literary works give effect to the readers. Even the literature can change the habits of a people. At some time literary works became a frightening or threatening government until the writers were exiled. In addition, literature is a mirror of life, because literary works are made as imitations of real life so that readers can benefit from the story of life. By exploring literature, readers can sharpen their conscience and humanity through the stories they read because the writers have inserted moral messages in their work.

Abrams said that pragmatic study is an approach to literary criticism that wants to show the impression and emotional impact of readers on literary works. The pragmatic study is based on the theory of literary reception in the literary understanding of literature which is a reaction to the weaknesses that are found in structural studies because this study was not able to do much in an effort to help someone in capturing and giving meaning to literary works. The structural study can only explain the surface layer of a literary text because it only talks about the structure or interruption of components in literary works. Many other aspects are needed to further explain the meaning of literary works, namely pragmatic studies. This pragmatic study is an approach that views literary works as a means to convey certain goals to the reader, such as education, religious morals and other goals. This study examines literary works based on their function to provide specific goals for the reader because the more values, teachings given to the reader, the better the literary work. Another definition (Siswanto, 2008: 181-191) says that pragmatic study is an approach to 
literary study that emphasizes its study of the role of the reader in accepting, understanding, and observing literary works. The reader has a role in determining whether a work is a literary work or not. Horatio in Art Poetica states that the poet's aim is to be useful or pleasant, or to provide benefits in life. From this opinion the pragmatic approach begins.

Klarer (1999: 92) explained that as a reaction to the dominant position of text-oriented criticism, a reader-oriented approach developed in the 1960s called reception theory, reader-response theory, or aesthetics of reception. All three terms are used almost synonymously to the pragmatic studies which focus on the reader's point of view in appreciating literary works. With the focus on the effect of a text on the receivers, reception theory demands an interpretation free of subjective contributions by the reader. The reader-centered approaches examine the readership of a text and investigate why, where, and when it is read. Those also examine certain reading practices of social, ethnic, or national groups. These approaches assume that a text creates certain expectations in the reader in every phase of reading. A further aspect which is closely connected with this movement is the investigation of the reception of texts by a particular readership. In reception history sales figures are examined together with reviews in newspapers and magazines. These analyses can either look at the reception of texts in one particular period as a synchronic analysis or trace changes and developments in the reception of texts in literary history as a diachronic analysis.

Damono in his book, Soiologi Sastra Sebuah Pengantar Ringkas (1978) explained that pragmatic studies give primary attention to the role of the reader, in relation to one of the modern theories, namely reception theory. The pragmatic studies are contrasted with expressive studies. The pragmatic and expressive study subjects as readers and writers share the same object, namely literary works. The difference is that the writer is the subject of the creator, but conversely, the reader who does not know about the process of creativity is considered as an artist. The pragmatic study is a field of literary study that emphasizes the study of the role of the reader and the approach to literary reception is a study that studies how the reader gives meaning to the literary work he is reading so that it can give a reaction or response to it, both passive and active responses. This pragmatic study has the benefit of the functions of literary works in society, their development and dissemination so that the benefits of literary works can be achieved. With the reader and literary indicators, the purpose of the pragmatic study is to benefit the reader. This study as a whole serves to support reception theory, that is, literary theory that enables understanding of the nature of literary works without limits. This study considers the readers' implication through various competencies. By considering these indicators, literary works and readers, the problems that can be solved through pragmatic studies, including various public responses to a literary work, both as an explicit reader or implicit, and both in a synchronous and diachronic framework. Theories of post structuralism are also based on the competence of the reader because the reader is the only one who succeeded in evacuating the cultural treasures of a nation. This study also views poetry as something that is built to achieve certain effects on the audience, reader or listener, both in the form of effects of aesthetic pleasure, teaching and education. This study tends to judge poetry based on the success or failure of achieving these goals. In addition, this study emphasizes aesthetic strategies to influence the reader's response to the problems raised in poetry. Two of the readers will receive different messages even though they are faced with the same poem. 


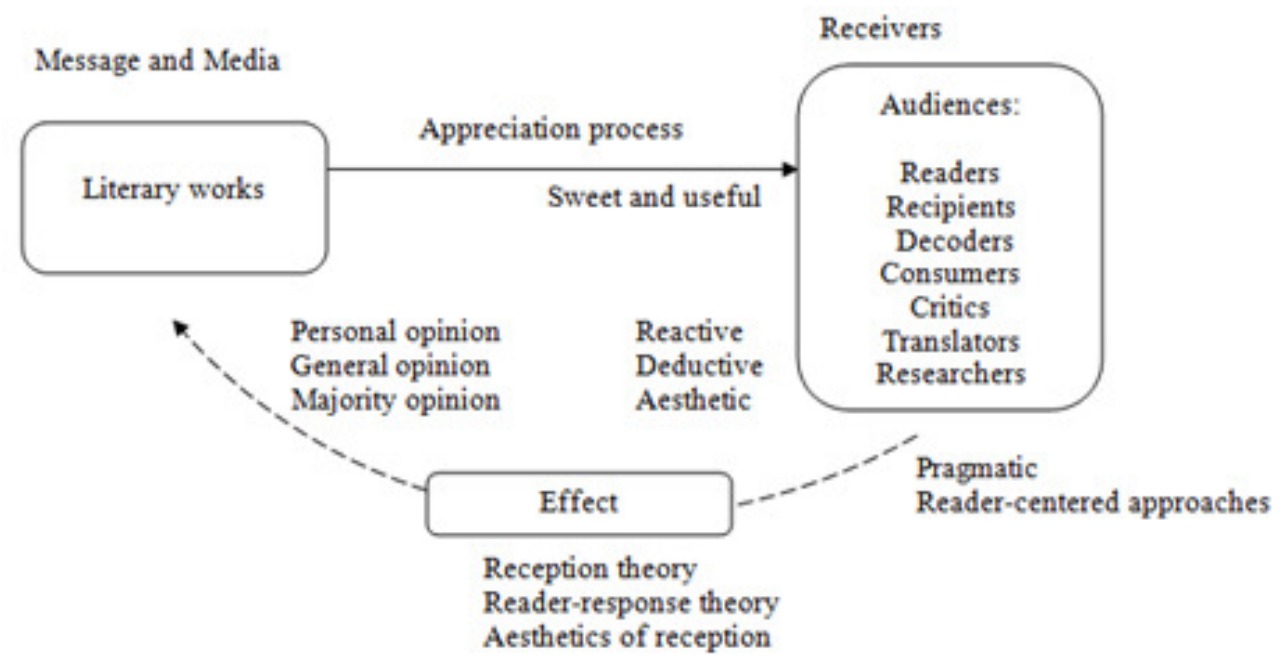

Figure 12 Pragmatic Studies

An addition to as review, the communication is generally distinguished by the nature category, which is grouped into two categories, namely verbal communication and non verbal communication. The verbal communication is a form of communication that uses verbal symbols. These verbal symbols can be translated into oral and written forms. can be carried out by two or more people through face to face contact directly without any distance or equipment that becomes the medium. The components of verbal communication can be seen in the activities of chatting carried out by people when they are in the office, school, campus, or other places. Apart from verbally, the verbal communication can also be done through writing. It is also can be in conventional correspondence, electronic mail, chat, and so forth while the on-verbal communication is a communication that is done without using words, but through other symbols. It can be demonstrated by the human body naturally through gestures, body language, facial expressions, and eye contact. Meanwhile, the non-verbal communication can also be shown from other things such as style of dress, haircuts, and tone of voice.

In line with the explanation, there are six types in the literary communication found from the relationship among the components. These relations refer to sorts of the literary communication which can be defined as follows.

(1) The relationship between the universe and the artist can occur consciously, subconsciously, and unconsciously when the artist observes all happenings or natural phenomena in the universe as the objective reality. The conscious communication is carried out consciously on the basis of the ratio assisted by the five senses and the implementing organs. Itresults in enriching knowledge that can be disseminated and reached by generations and down through general education. It also takes place through the inner layer called the sixth sense, which is referred to as the subconscious and unconscious communication through the inner can be done by literary artists with anything in the universe for various things. Every literary artist was born with this ability, but only a limited number developed it to a certain extent. This relation represents a mimetic communication.

(2) The relationship between the personality and the artist occurs among the artist and his mind structure as well as his awareness levels when he keeps any phenomena subjectively to produce a consideration of what he observes so that this relation can be a subjective communication. In the process of observing natural phenomena, the artist 
cooperates with his personality, namely the structure of his mind and the level of consciousness as consideration for deciding something related in an effort to convey it as a message.

(3) The relationship between the previous works and the artist occurs when the artist creates ideas to produce message of course by seeing any message texts both actually and potentially becauseit bases itself on other previous works, both directly and indirectly, either by continuing, deviating, rejecting, or distorting the essence. This relation can be called as a hyprogram or intertextuality communication.

(4) The relationship between the artist and the message occurs when the artist deliver the message, which is based on his ideas composition, then he must transmit it into the literary works form. This relation can be called as an expressive, creative, imaginative, and professional communication.

(5) The relationship between the message and the receivers occurs when the receiver accepts any appreciations of the message. Because the message in the literary work is the theme or main ideas mediated by figurative languages, the receiver can accept the message such as personal, general or majority opinion. These opinions can be either entertaining, educate or both. This relation can be called as an appreciation communication.

(6) The communication between the receiver and the effects occurs when the receivers respond the message. The responses are effects as the result of appreciation process such as reactive, deductive, and aesthetic. This relation can be called as a pragmatic communication.

\section{CONCLUSION}

Results of Synchronizing between Lasswell's Communication Model and Abram's Critical Orientation as a Sophisticated Concept of Literary Communication and Its Associated Studies can be concluded that as follows.

The components of literary communication consist of (1) the source of the ideas influenced by the universe, personality, and previous works. (2) the communicator is the artist can be author, poet, playwright acting ascreator, sender, encoder producer, (3)the message is themain idea in literary work, (4) the media or channel is language delivering the message in the literary work, and (5) the receiver is the audience acting as reader, recipient, decoder, critic, translator, researcher, and (6) the effect is the feedback as the response of the receiver.

The studies of each component is that (1) the mimetic or context-oriented approach is a study focuses on the relation between the literary text and the extra-textual universe which provides the sources and stimuli for what the literary text actually representsliterary study (2) the expressive or author-oriented approach is a study focuses on the relation between the literary text and the artist od the literary text,(3) the objective or text-oriented approach is a study focuses on the relation between the literary text and its distinctively literary devices., and (4) the pragmatic or reader-oriented approach, a study focuses on the relation between the literary text and the reader of the literary text.

The sorts of communication in literature can be (1) the relationship between the universe and the artist can occur consciously, subconsciously, and unconsciously when the artist observes all happenings or natural phenomena in the universe as the objective reality. This relation represents a mimetic communication, (2) the relationship between the personality 
and the artist occurs among the artist and his mind structure as well as his awareness levels when he keeps any phenomena subjectively to produce a consideration of what he observes so that this relation can be a subjective communication, (3) the relationship between the previous works and the artist occurs when the artist creates ideas to produce message of course by seeing any message texts both actually and potentially because it bases itself on other previous works, both directly and indirectly, either by continuing, deviating, rejecting, or distorting the essence. This relation can be called as a hyprogram or intertextuality communication, (4) the relationship between the artist and the message occurs when the artist delivers the message, which is based on his ideas composition, and then he must transmit it into the literary works form. This relation can be called as an expressive, creative, imaginative, and professional communication, (5) the relationship between the message and the receivers occurs when the receiver accepts any appreciations of the message. This relation can be called as an appreciation communication, and (6) the communication between the receiver and the effects occurs when the receivers respond the message. This relation can be called as a pragmatic communication.

\section{REFERENCES}

Abrams, M.H. (1953). The Mirror and The Lamp: Romantic theory and Critical Tradition. London: Oxford University Press.

Allen, Graham.(2000). Intertextuality. London: Graham Allen. Berger. Charles R, Michael E Roloff, and David R Roskos-Ewoldsen. (2010). The Handbook of Communication Science. Californisa: Sage.

Bressler, Charles. 1999. Literary Criticism.United State of America; Prentice-Hall International UK, London.

Damono, Sapardi Djoko. (1978). Sosiologi Sastra Sebuah Pengantar Ringkas. Jakarta: Pusat Pembinaan dan Pengembangan Bahasa

Esten, Mursal. (1978). Kesusastraan : Pengantar, Teori dan Sejarah. Bandung : Angkasa

Fiske, John. 1990. Introduction to Communication Studies. London: Routledge.

Foucault, Michel. 1974. The Archaeology of Knowledge. London: Tavistock.

Freaud, Sigmund. (1989). An Outline of Psycho-Analysis. New York, London: WW. Norton and Company.

Klarer, Mario. 1999. An Introduction to Literary Studies. London: Routledge.

Lasswell, H. D. (1948). The Structure and Function of Communication in Society.

Bryson (Ed.). The Communication of Ideas (Pp. 37-51). New York: Harper and Row. Retrieved from https://pracownik.kul.pl/files/37108/public/Lasswell.pdf

Luxemburg, Jan van, et al. (1989). Pengantar Ilmu Sastra. Translated by Dick Hartoko. Jakarta: Gramedia. 
McCombs, Maxwell and Donald L. Shaw. (2010). Lasswell's Communication Model.

Communication Theory. Retrieved from: http://communicationtheory.org/lasswellsmodel/.on Dec 22013.

Mikics, David. (2007). A New Handbook of Literary Term. London: Yale University Press.

Nurudin. (2005). Sistem Komunikasi Indonesia. Yogyakarta : Bigraf Publishing.

Plett, Heinrich F (ed). 1991. Intertextuality. Berlin and New York: Walter de Gruyter.

Pradopo, Rachmat Djoko. (2002). Kritik Sastra Indonesia Modern. Yogyakarta: Gama Media.

Pradopo, Rachmat Djoko. (2005). Beberapa Teori Sastra, Metode Kritik, dan Penerapannya. Yogyakarta: Pustaka Pelajar.

Pradopo, Rahmat Djoko. (2010). Pengkajian Puisi. Yogyakarta: Gadjah Mada University Press.

Rakhmat, Jalaluddin. (1984). Psikologi Komunikas. Bandung : PT Remaja Rosdakarya.

Ratna, Nyoman Kutha. (2008). Teori, Metode, dan Teknik Penelitian Sastra: dari Strukturalisme hingga Postrukturalisme, Prespektif Wacana Naratif. Yogyakarta: Pustaka Pelajar.

Riffaterre, Michael. (1978). Semiotics of Poetry. Bloomington and Indiana: University Press.

Sarumpet, Riri K Toha. (2010). Pedoman Pendidikan Sastra Anak. Jakarta: Yayasan Pustaka Obor Indonesia.

Segers, Rien T. (2000). Evaluasi Teks Sastra. Translated by Suminto A. Sayuti. Yogyakarta: Adi Cita.

Semi, M Atar. (1984). Anatomi Sastra. Padang: FPBSIKIP.

Siswanto, Wahyudi. (2008). Pengantar Teori Sastra. Malang: GRASINDO.

Steinberg, Sheila. (2007). An Introduction to Communication Studies. Cape Town: Juta\&Co.

Shoemaker, Pamela. Tankard Jr., J.; Lasorsa, D. 2004. How to Build Social Science Theories. Thousand Oaks: Sage Publications.

Sumardjo, Jacob. Saini K.M. (1997). Apresiasi Kesusastraan. Jakarta: Gramedia.

Saryo no. (2009). Pengantar Apresiasi Sastra. Malang: Universitas Negeri Malang.

Teeuw, A. (1991). Sastra dan Ilmu Sastra dan Pengantar Teori Sastra. Jakarta: Pustaka Jaya. 
Van Rooden, A. ( 2012). Magnifying the Mirror and the Lamp: A Critical Reconsideration of the Abramsian Poetical model and Its Contibution to The Research on Modern Dutch Literature. Journal of Dutch Literature, 3(1), 65-87. Retrieved from https://pure.uva.nl/ws/files/1181761/116638_Van_Rooden_Magnifying_the_Mirr or_and_the_Lamp.pdf

Widjaja, H. A. W. (2000). Ilmu Komunikasi Pengantar Studi, Jakarta : PT Rineka Cipta.

Wenxiu, Peng. (2015). Analysis of New Media Communication Based on Lasswell's " 5 W" Model. Journal of Educational and Social Researc Vol. 5 No.3 ISSN 2240-0524. Doi:10.5901/jesr.2015.v5n3p245. Rome-Italy: MCSER Publishing.

Wellek, Rene and Austin Warren. 1984. Theory of Literature. San Diego, New York, London: Harcourt Brace and Company.

Worton, Micheal. Judith Still (eds). 1990. Intertextuality: Theories and Practices. Manchester: Manchester University Press. 